\title{
Kinetic and equilibrium study of Ni(II) sorption from aqueous solutions onto Peganum harmala-L
}

\author{
M. Ghasemi $\cdot$ N. Ghasemi $\cdot$ G. Zahedi $\cdot$ \\ S. R. W. Alwi • M. Goodarzi - H. Javadian
}

Received: 1 September 2012/Revised: 20 April 2014/Accepted: 10 May 2014/Published online: 11 June 2014

(C) Islamic Azad University (IAU) 2014

\begin{abstract}
In this study, the adsorption behavior of $\mathrm{Ni}(\mathrm{II})$ in an aqueous solution system using natural adsorbent Peganum harmala-L was measured via batch mode. The prepared sorbent was characterized by scanning electron microscope, Fourier transform infrared spectroscopy, $\mathrm{N}_{2}$ adsorptiondesorption and $\mathrm{pH}_{\mathrm{zpc}}$. Adsorption experiments were carried out by varying several conditions such as contact time, metal ion concentration and $\mathrm{pH}$ to assess kinetic and equilibrium parameters. The equilibrium data were analyzed based on the Langmuir, Freundlich, Temkin and Dubinin-Radushkevich isotherms. Kinetic data were analyzed using the pseudo-firstorder, pseudo-second-order and intra-particular diffusion models. Experimental data showed that at contact time $60 \mathrm{~min}$, metal ion concentration $50 \mathrm{mg} / \mathrm{L}$ and $\mathrm{pH}$ 6, a maximum amount of $\mathrm{Ni}$ (II) ions can be removed. The experimental
\end{abstract}

M. Ghasemi · N. Ghasemi $(\bowtie)$

Department of Chemistry, Sciences Faculty, Arak Branch, Islamic Azad University, Arāk, Iran

e-mail: n-ghasemi@iau-arak.ac.ir

N. Ghasemi · S. R. W. Alwi

Process Systems Engineering Centre (PROSPECT), Faculty of Chemical Engineering, Universiti Teknologi Malaysia (UTM), 81310 Skudai, Johor, Malaysia

G. Zahedi

Chemical \& Biological Engineering Department, Missouri University of Science \& Technology, Rolla, MO, USA

M. Goodarzi

Department of Biosystems, Faculty of Bioscience Engineering, Katholieke Universiteit Leuven - KULeuven, Kasteelpark Arenberg 30, 3001 Heverlee, Belgium

H. Javadian

Department of Chemical Engineering, Shahrood Branch, Islamic Azad University, Shahrood, Iran data were best described by the Langmuir isotherm model as is evident from the high $R^{2}$ value of 0.988 . The adsorption capacity $\left(q_{\mathrm{m}}\right)$ obtained was $68.02 \mathrm{mg} / \mathrm{g}$ at an initial $\mathrm{pH}$ of 6 and a temperature of $25{ }^{\circ} \mathrm{C}$. Kinetic studies of the adsorption showed that equilibrium was reached within 60 min of contact and the adsorption process followed the pseudo-first-order model. The obtained results show that $P$. harmala-L can be used as an effective and a natural low-cost adsorbent for the removal of $\mathrm{Ni}(\mathrm{II})$ from aqueous solutions.

Keywords Adsorption - Isotherm - Kinetic - Natural adsorbent $\cdot \mathrm{Ni}(\mathrm{II}) \cdot$ Peganum harmala-L

\section{Introduction}

Modernization and industrialization have led to a heavy influx of pollutants into the environment. Contamination of the environment by heavy metal ions is a serious problem due of their toxic effects on human health and living organisms. The metals are of special concern because they are non-degradable and, thus, persistent. Heavy metals such as cadmium, lead, zinc, nickel, copper, mercury and chromium or their compounds have been recognized as hazardous pollutants. Because of their toxicity, the presence of any of these metals in excessive quantities in water will spoil it (Kalavathy et al. 2010).

Nickel is a toxic metal found in wastewaters. More than $40 \%$ of the produced nickel is used in steel factories and in nickel batteries. The production of some alloys causes an increase of the $\mathrm{Ni}$ (II) burden on the ecosystem and deterioration in water quality. Its concentrations in industrial wastewaters range from 3.4 to $900 \mathrm{mg} / \mathrm{L}$, and the maximum contaminant limit for nickel in potable water has been fixed at $50 \mu \mathrm{g} / \mathrm{L}$ by the European Economic Community (Demirbas et al. 2002). 
Among the many available methods to reduce heavy metal concentration from wastewater, the most commonly used are chemical precipitation (Zhang et al. 2009), ionexchange (Dai et al. 2010), adsorption and reverse osmosis (Zou et al. 2010). Most of these methods suffer from some drawbacks such as high capital and operational costs as well as the problem of the disposal of residual metal sludge (Hui et al. 2005). However, adsorption has been found to be superior to other techniques for wastewater treatment in terms of initial cost, simplicity of design, ease of operation and insensitivity of toxic substances (Mahmoodi et al. 2011). Activated carbon adsorbents are widely used in the removal of heavy metal contaminants. Its usefulness derives mainly from its large micropore and mesopore volumes and the resulting high surface area. Biosorption of heavy metals from aqueous solutions is a relatively new process that has been confirmed to be a very promising process in the removal of heavy metal contaminants. The major advantages of biosorption are its high effectiveness in reducing the heavy metal ions and the use of inexpensive biosorbents (Fu and Wang 2011). Peganum harmala-L is a perennial, bushy and wild-growing flowering plant with short-creeping roots which may grow up to $30-100 \mathrm{~cm}$ high (Darabpour et al. 2011). It is a common plant in the Middle Eastern countries such as Pakistan, India and Iran, and it is still used traditionally to treat several diseases (El Gendy and El-Kadi 2009). The plant has also been used as an antimicrobial, antitumoral, in curing malaria and has insecticidal potential (Goel et al. 2009).

The main goal of this study was to remove $\mathrm{Ni}(\mathrm{II})$ from aqueous solutions by using Peganum harmala- $\mathrm{L}$ as a natural adsorbent (PHNA) and to investigate the influence of different parameters involved during the sorption process such as contact time, metal ion concentration and $\mathrm{pH}$. This adsorbent was characterized using scanning electron microscope (SEM), Fourier transform infrared spectroscopy (FTIR), $\mathrm{N}_{2}$ adsorption-desorption and $\mathrm{pH}_{\mathrm{zpc}}$. The kinetic and equilibrium parameters were determined. The parameters of adsorption isotherm models were also investigated. This study was carried out in October 2011 in the laboratory of the Department of Chemistry Islamic Azad University, Arak branch.

\section{Materials and methods}

Adsorbent

Peganum harmala-L seeds were collected in Arak, Iran. Biomass was air-dried, washed several times with deionized water to remove the impurities and then dried in an oven at $105{ }^{\circ} \mathrm{C}$ for $12 \mathrm{~h}$. Biomass was grounded into powdered form and sieved to the particle size $0.707 \mathrm{~mm}$.
Adsorbate

A stock solution of $2,000 \mathrm{mg} / \mathrm{L}$ of $\mathrm{Ni}(\mathrm{II})$ was prepared by dissolving a necessary amount of analytical reagent grade $\mathrm{Ni}\left(\mathrm{NO}_{3}\right)_{2} \cdot 6 \mathrm{H}_{2} \mathrm{O}$ salt in twice distilled water. Working solutions of the desired concentration were then prepared by successive dilution. Before mixing the adsorbate with the adsorbent, the initial $\mathrm{pH}$ of each solution was adjusted to the required value by adding $0.1 \mathrm{M} \mathrm{H}_{2} \mathrm{SO}_{4}$ and $0.1 \mathrm{M} \mathrm{NaOH}$ solutions.

\section{Characterization of the adsorbent}

The microstructure of the adsorbent was examined by scanning electron microscope (SEM, Hitachi S4160). FTIR analysis of the used adsorbent was performed using FTIRFDU-3, DR-11. In total, $5 \mathrm{mg}$ of sample was mixed with $500 \mathrm{mg}$ of $\mathrm{KBr}$ powder and then the mixture was carefully ground and well mixed. The $\mathrm{N}_{2}$ adsorption-desorption isotherms were measured at $-196{ }^{\circ} \mathrm{C}$ (Model: Belsorb) volumetric adsorption analyzer. For $\mathrm{pH}_{\mathrm{pzc}}$ determination, $0.1 \mathrm{M} \mathrm{NaCl}$ was prepared and its $\mathrm{pH}$ was adjusted in the range of $2-10$ by adding $\mathrm{NaOH}$ or $\mathrm{HCl}$. Each flask was filled with $20 \mathrm{~mL}$ of $\mathrm{NaCl}$ solution and $0.1 \mathrm{~g}$ of PHNA. These flasks were kept for $2 \mathrm{~h}$, and the final $\mathrm{pH}$ of the solution was measured by using a $\mathrm{pH}$ meter. Graphs were then plotted for $\mathrm{pH}$ final versus $\mathrm{pH}$ initial.

\section{Adsorption experiments}

The effect of $\mathrm{pH}$ on $\mathrm{Ni}(\mathrm{II})$ adsorption was investigated by agitating $0.1 \mathrm{~g}$ of adsorbent and a series of $20 \mathrm{~mL} \mathrm{Ni(II)}$ solutions with a concentration of $50 \mathrm{mg} / \mathrm{L}$ at different $\mathrm{pH}$ values, ranging from $\mathrm{pH} 2-10$. The samples were agitated for $60 \mathrm{~min}$ to reach equilibrium. The effects of initial metal concentration $50-2,000 \mathrm{mg} / \mathrm{L}$ and contact time 1-60 min were investigated at fixed values of $\mathrm{pH} 6$, adsorbent size and dosage $0.707 \mathrm{~mm}$ and $0.1 \mathrm{~g}$, respectively, and shaking speed $150 \mathrm{rpm}$.

The equilibrium studies were carried out by adding $0.1 \mathrm{~g}$ of the adsorbent with $20 \mathrm{ml}$ of different concentration of $\mathrm{Ni}$ (II) solutions $50-2000 \mathrm{mg} / \mathrm{L}, \mathrm{pH} 6$, for $14 \mathrm{~h}$ at $150 \mathrm{rpm}$ and $25{ }^{\circ} \mathrm{C}$. After a preset contact time, the samples were separated from the solution by filtration through the filter paper. The exact concentration of the residual metal ion in the filtrate was analyzed by an atomic absorption spectrometer (Shimadzu AA-680, Japan).

In order to obtain the sorption capacity $q_{\mathrm{e}}$, the amount of ions adsorbed per unit mass of adsorbent $\left(\mathrm{mg} \mathrm{g}^{-1}\right)$ at equilibrium contact time was calculated by using the following Eq. (1):

$q_{\mathrm{e}}=\frac{C_{\mathrm{O}}-C_{\mathrm{e}}}{m} \times V$ 
where $C_{\mathrm{o}}$ is the initial metal ion concentration $(\mathrm{mg} / \mathrm{L}), C_{\mathrm{e}}$ is the equilibrium metal ion concentration $(\mathrm{mg} / \mathrm{L}), V$ is the volume of the aqueous phase (L), and $\mathrm{m}$ is the amount of the adsorbent used $(\mathrm{g})$.

\section{Results and discussion}

\section{Characterization of Peganum harmala-L}

The SEM is widely used to study the morphological features and surface characteristics of adsorbent materials (Huang et al. 2011). The surface functional groups of the adsorbent, besides the porous structure, are of vital importance in understanding the sorption process and the adsorption capacity of an adsorbent (Lalhruaitluanga et al. 2011). SEM micrograph with different magnification of PHNA is shown in Fig. 1a, b. The surface morphology of PHNA indicated that its surface was porous and smooth which could be seen clearly. Figure 1c, d showed the adsorbent's FTIR spectra, before and after adsorption of nickel. The samples showed a wideband located around 3,401 and $3,414 \mathrm{~cm}^{-1}$, which was ascribed to $\mathrm{O}-\mathrm{H}$ stretching. The bands around 2,925 and $2,929 \mathrm{~cm}^{-1}$ were usually caused by the $\mathrm{C}-\mathrm{H}$ stretching vibration of $\mathrm{CH}_{2}$ (Zhu et al. 2012). The IR spectra indicated weak and broad peaks about 1,631 and $1,635 \mathrm{~cm}^{-1}$ corresponding to $-\mathrm{C}-\mathrm{OH}$ groups stretching from aldehydes and ketones. Peaks around $1,460 \mathrm{~cm}^{-1}$ are indicative of $\mathrm{CH}_{2}$ and $\mathrm{CH}_{3}$ groups are observed in sample before adsorption. The peaks at the 1,383 and $1,384 \mathrm{~cm}^{-1}$ band may be attributed to the aromatic $\mathrm{CH}$ and carboxyl-carbonate structures and to silanol groups (Gupta et al. 2012). The FTIR spectrum of PHNA indicates significant changes after adsorption. These shifts in peak frequencies indicate that there were binding processes taking place on the surface of carbon (Lalhruaitluanga et al. 2011). The $\mathrm{N}_{2}$ adsorption-desorption isotherm gives information about the porosity of the adsorbent. The isotherm-powdered PHNA shows IUPAC Type IV adsorption isotherm which is the characteristic of mesoporous materials (Fig. 1e). The $\mathrm{pH}_{\mathrm{ZPC}}$, determined as the $\mathrm{pH}$ at which the adsorbent surface has a net electrical neutrality, is a very important surface characteristic of an adsorbent. The $\mathrm{pH}_{\mathrm{pzc}}$ value of the studied adsorbent is lower than 7 (Fig. 1f). It can be seen from Fig. 1f, PHNA surface is negatively charged at solution $\mathrm{pH}$ values above 7 and at $\mathrm{pH}$ values below 7, the surface of PHNA is positively charged.

Effect of contact time and initial metal ion concentration

Figure 2a shows the results for the effect of contact time on the uptake $\mathrm{Ni}(\mathrm{II})$ from aqueous solution at an initial concentration of $50(\mathrm{mg} / \mathrm{L})$. The obtained results show that the adsorption increases by increasing contact time. It is clear from the graph that a rapid uptake of $\mathrm{Ni}$ (II) ions occurred during the first $20 \mathrm{~min}$ of agitation, after which the rate of sorption became slower, attaining equilibrium in $60 \mathrm{~min}$. Further increase in contact time had negligible effect on the amount of ions adsorbed.

Figure $2 \mathrm{~b}$ indicates that the uptake of $\mathrm{Ni}(\mathrm{II})$ ions increases with the increment of initial $\mathrm{Ni}$ (II) ions concentration from 50 to $2,000 \mathrm{mg} / \mathrm{L}$. According to SenthilKumar et al. (2011), at lower metal ions concentrations, the percentage uptake was higher due to the larger surface area of the adsorbent being available for adsorption. When the concentration of $\mathrm{Ni}$ (II) ions became higher, the percentage removal decreased since the number of available sites for adsorption reduced due to saturation of adsorption sites. At a higher concentration of $\mathrm{Ni}$ (II) ions, the ratio of initial number of moles of $\mathrm{Ni}$ (II) ions to the adsorption sites available was higher, resulting in lower adsorption percentage.

\section{Effect of $\mathrm{pH}$}

The effect of $\mathrm{pH}$ on the adsorption of $\mathrm{Ni}(\mathrm{II})$ by PHNA in the range from 2 to 10 is presented in Fig. 3. The biosorption capacity was found to be affected by equilibrium $\mathrm{pH}$, although it is not easy to control the equilibrium $\mathrm{pH}$ at the end of the reaction (Ho and Ofomaja 2006). The $\mathrm{pH}$ of the aqueous solution was an important parameter that controlled the adsorption process. Adsorption of different metals is optimized at different $\mathrm{pH}$ values (Wahi et al. 2010). The type of biomass used also influences the optimum $\mathrm{pH}$ for metal adsorption (Jamali et al. 2009). The maximum value of metal retention occurred approximately at $\mathrm{pH}$ 6.0. It can be observed that there is an increase in uptake of Ni ions from 0.172 to $6.38 \mathrm{mg} / \mathrm{g}$ in solution with increased pH from 2 to 6 (Carvalho et al. 2008). A competition for the surface sorption sites occurred between protons and heavy metal ions. A higher $\mathrm{pH}$ value $(>7)$ can lead to more precipitation of metal hydroxides that make a predominant contribution to the removal of metal ions (Colak et al. 2013).

\section{Adsorption isotherms}

The analysis of the isotherm data is important to develop an equation which accurately represents the results and could be used for design purposes. In order to investigate the sorption isotherm, four equilibrium models were analyzed: Langmuir, Freundlich, Temkin and Dubinin-Radushkevich (D-R) isotherm equations. 

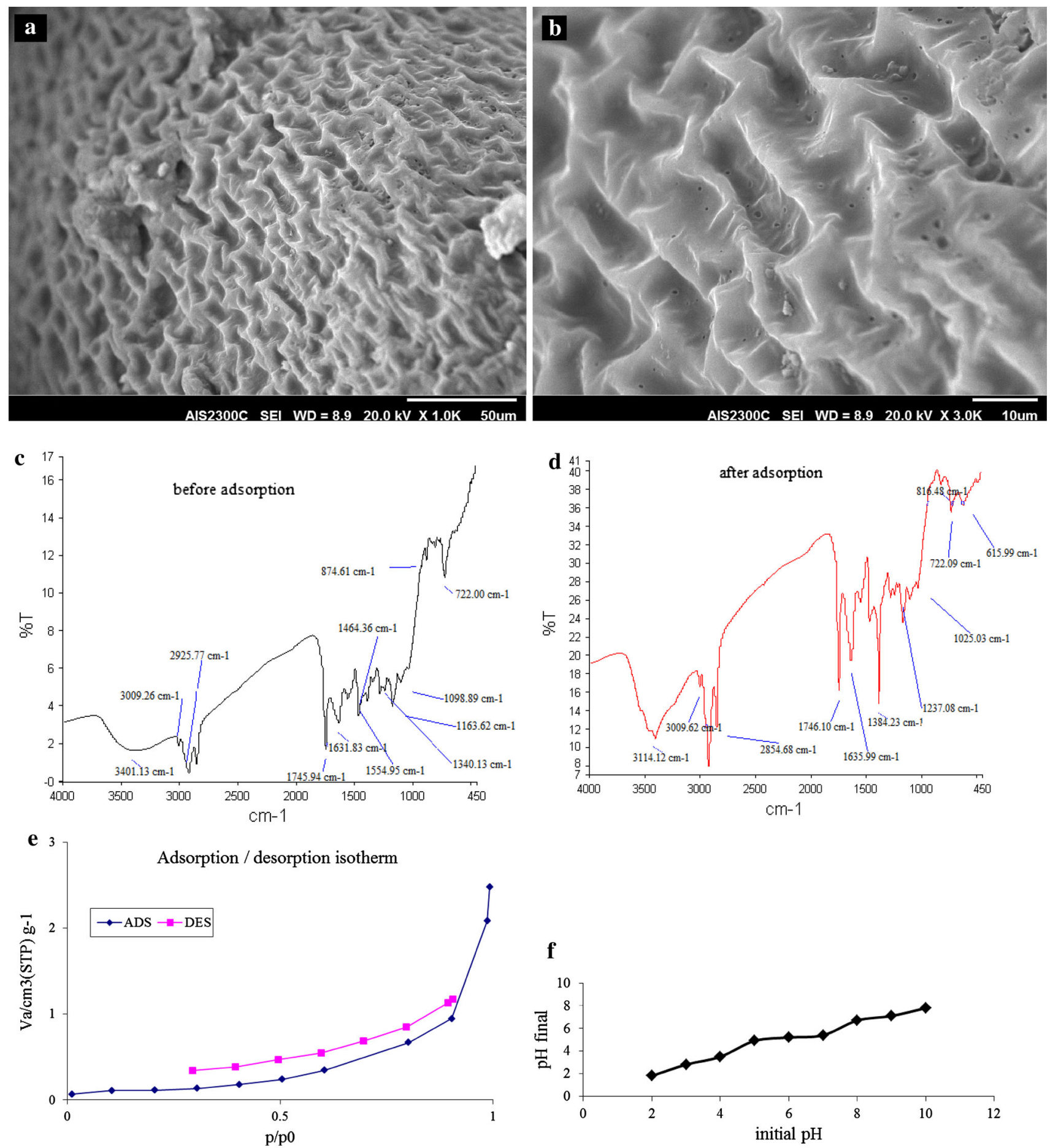

Fig. 1 a, b FESEM image of the PHNA with different magnification, $\mathbf{c}$ FTIR spectra of PHNA before, $\mathbf{d}$ after adsorption, e $\mathrm{N}_{2}$ adsorptiondesorption isotherm of PHNA, $\mathbf{f}$ plot of $\mathrm{pH}$ final against the initial $\mathrm{pH}$ of PHNA

\section{Langmuir isotherm model}

The Langmuir sorption isotherm is the best known of all isotherms describing sorption (Hui et al. 2005; Langmuir 1918) and is based on assumptions: (a) Maximum adsorption corresponds to a saturated monolayer of adsorbate molecules on the adsorbent surface

(b) The energy of adsorption is constant 

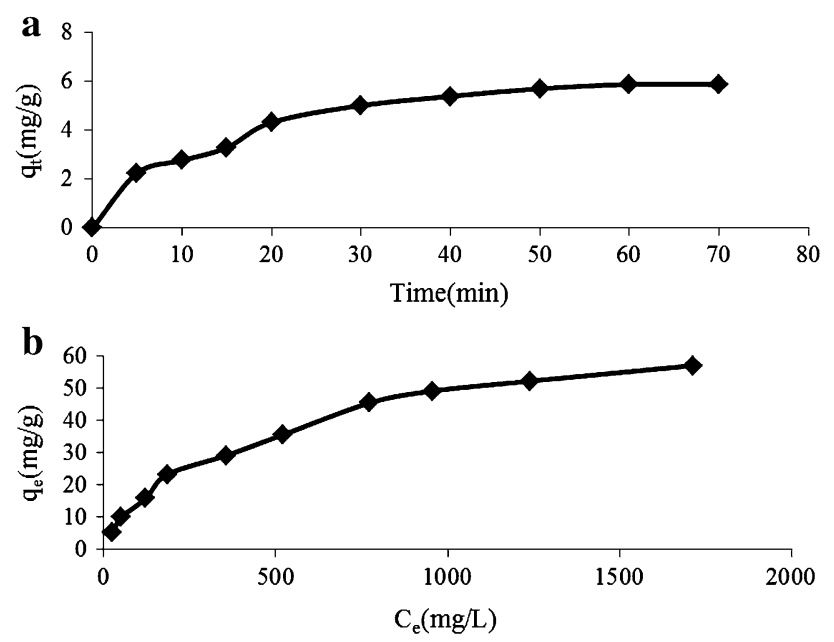

Fig. 2 a Effect of contact time on the adsorption of $\mathrm{Ni}(\mathrm{II})$ by PHNA(condition: $25{ }^{\circ} \mathrm{C} ; 150 \mathrm{rpm} ; 20 \mathrm{ml}$ of $50 \mathrm{mg} / \mathrm{L}$ of $\mathrm{Ni}$ (II) solution; $\mathrm{pH} 6 ; 0.1 \mathrm{~g}$ of PHNA). b Effect of initial concentration on the adsorption of $\mathrm{Ni}(\mathrm{II})$ by PHNA(condition: $25^{\circ} \mathrm{C}$; $150 \mathrm{rpm}$; $\mathrm{pH}$ 6; $20 \mathrm{ml}$ of $50-2,000 \mathrm{mg} / \mathrm{L}$ of $\mathrm{Ni}(\mathrm{II})$ solutions; $0.1 \mathrm{~g}$ of PHNA)

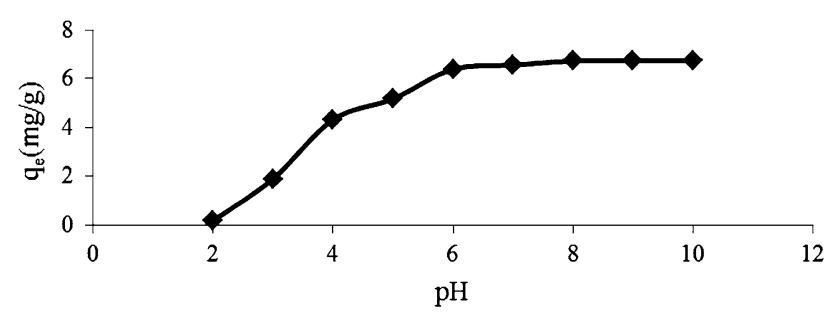

Fig. 3 Effect of $\mathrm{pH}$ on the adsorption of $\mathrm{Ni}(\mathrm{II})$ by PHNA(condition: $25{ }^{\circ} \mathrm{C} ; 150 \mathrm{rpm} ; 20 \mathrm{ml}$ of $50 \mathrm{mg} / \mathrm{L}$ of $\mathrm{Ni}(\mathrm{II})$ solution; $0.1 \mathrm{~g}$ of PHNA)

(c) There is no transmigration of adsorbate in the plane of the surface linear expression of this model has been demonstrated as follows:

$\frac{C_{\mathrm{e}}}{q_{\mathrm{e}}}=\frac{1}{b q_{m}}+\frac{C_{\mathrm{e}}}{q_{m}}$

where $q_{\mathrm{e}}$ is the amount of $\mathrm{Ni}$ (II) ions adsorbed at equilibrium $(\mathrm{mg} / \mathrm{g}), C_{\mathrm{e}}$ is the concentration of $\mathrm{Ni}(\mathrm{II})$ ions at equilibrium $(\mathrm{mg} / \mathrm{L}), q_{\mathrm{m}}$ is the maximum adsorption capacity $(\mathrm{mg} / \mathrm{g})$, and $\mathrm{b}$ is the Langmuir isotherm constant related to the energy of adsorption $(\mathrm{L} / \mathrm{mg})$. The values of $q_{\mathrm{m}}$ and b can be determined from the linear plot of $C_{\mathrm{e}} / q_{\mathrm{e}}$ versus $C_{\mathrm{e}}$ (Esmaili-Sari et al. 2013). The linear plot of the Langmuir isotherm at a temperature $25^{\circ} \mathrm{C}$ is shown in Fig. $4 \mathrm{a}$, and the model parameters at $25^{\circ} \mathrm{C}$ are listed in Table 1.

According to ALzaydien (ALzaydien 2009), the essential characteristics of the Langmuir isotherm can be expressed in terms of a dimensionless constant separation factor $R_{\mathrm{L}}$, which is given in Eq. (3):
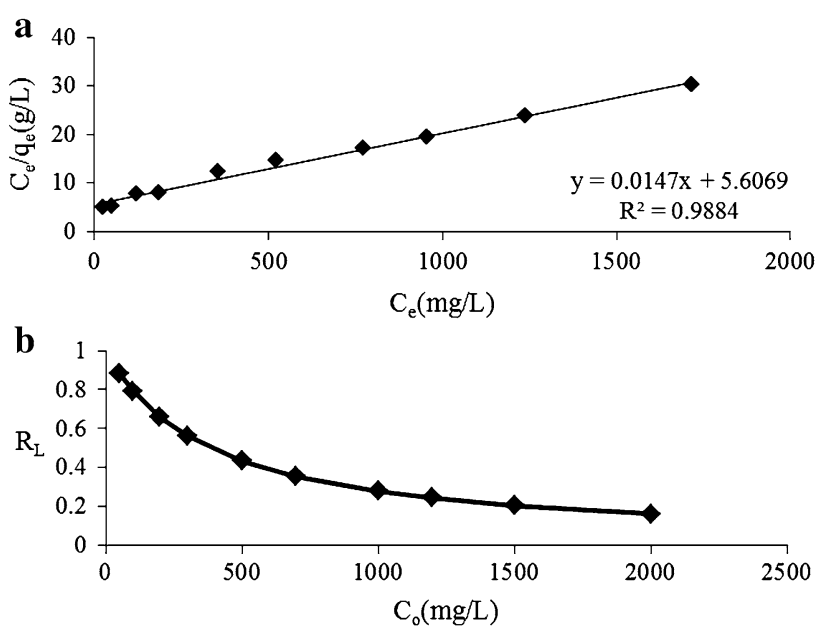

Fig. 4 a Langmuir isotherm on the adsorption of Ni(II) by PHNA and $\mathbf{b}$ the $R_{\mathrm{L}}$ values obtained for adsorption of $\mathrm{Ni}(\mathrm{II})$ by PHNA in the concentration range studied

$R_{\mathrm{L}}=\frac{1}{1+b C_{\mathrm{O}}}$

The value of the separation factor $R_{\mathrm{L}}$ indicates the shape of the isotherm that can be represented by following Table 2 (Ghasemi et al. 2014). The $R_{\mathrm{L}}$ values were calculated using the equilibrium sorption data obtained at $25^{\circ} \mathrm{C}$, and the $R_{\mathrm{L}}$ values obtained were in the range of 0 and 1 , which indicated a favorable isotherm shape for adsorption of $\mathrm{Ni}(\mathrm{II})$ ions onto PHNA in the concentration range studied (Fig. 4b).

Freundlich isotherm model

The Freundlich isotherm is most frequently used to describe the adsorption of inorganic and organic components in a solution (Namasivayam et al. 2003). This fairly satisfactory empirical isotherm can be used for a non-ideal sorption that involves heterogeneous sorption. Linear expression of this model is given by the following equation:

$\log q_{\mathrm{e}}=\log k_{\mathrm{f}}+\frac{1}{n} \log C_{\mathrm{e}}$

Where $K_{\mathrm{f}}$ is roughly an indicator of the adsorption capacity and $\mathrm{n}$ is the adsorption intensity. The values of $n$ could give an indication on the favorability of sorption, where $n<1,1<n<2$ and $2<n<10$ represent poor, moderately difficult and favorable adsorption conditions, respectively (Chen et al. 2010). By plotting $\log q_{\mathrm{e}}$ versus $\log C_{\mathrm{e}}$ (Fig. 5a), values of $K_{\mathrm{f}}$ and $\mathrm{n}$ can be determined from the slope and intercept of the plot. The values of $K_{\mathrm{f}}$ and $\mathrm{n}$ obtained from the plot were 1.018 and 1.779 , respectively (Table 1). The value of $\mathrm{n}$ showed the moderate difficulty of 
Table 1 Isotherms constants for Ni(II) adsorption onto PHNA at different initial concentrations

\begin{tabular}{|c|c|c|c|c|c|c|c|c|c|c|c|c|c|}
\hline \multirow{2}{*}{$\frac{\text { Metal }}{\mathrm{Ni}}$} & \multicolumn{3}{|c|}{ Langmuir constants } & \multicolumn{3}{|c|}{ Freundlich constants } & \multicolumn{3}{|c|}{ Temkin constants } & \multicolumn{4}{|c|}{ D-R constants } \\
\hline & $q_{\mathrm{m}}$ & $b$ & $R^{2}$ & $n$ & $k_{\mathrm{f}}$ & $R^{2}$ & $B$ & $A$ & $R^{2}$ & $K$ & $q_{\mathrm{m}}$ & $R^{2}$ & $E_{\mathrm{s}}$ \\
\hline & 68.02 & 0.002 & 0.988 & 1.779 & 1.018 & 0.979 & 12.81 & -25.27 & 0.964 & 435.3 & 34.22 & 0.689 & 0.033 \\
\hline
\end{tabular}

Table $2 R_{\mathrm{L}}$ values for Langmuir isotherm

\begin{tabular}{ll}
\hline Value of $R_{\mathrm{L}}$ & Type of adsorption \\
\hline$R_{\mathrm{L}}=0$ & Irreversible \\
$0<R_{\mathrm{L}}<1$ & Favorable \\
$R_{\mathrm{L}}=1$ & Linear \\
$R_{\mathrm{L}}>1$ & Unfavorable \\
\hline
\end{tabular}
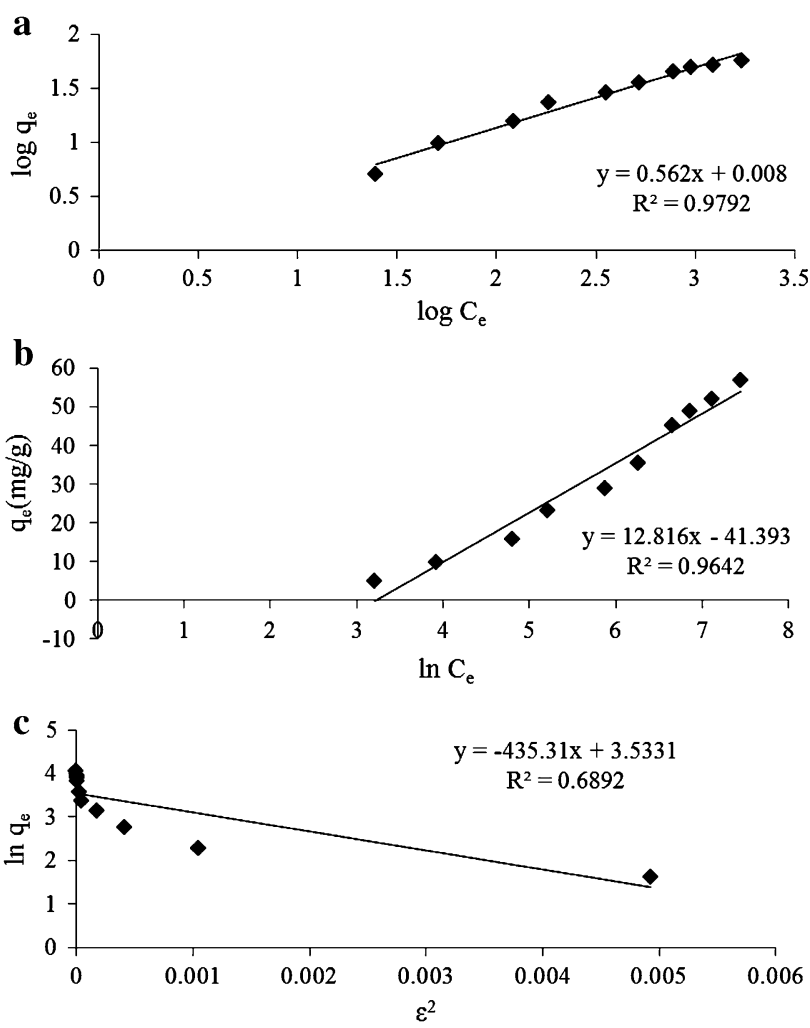

Fig. 5 a Freundlich isotherm, b Temkin isotherm and c DubininRadushkevich isotherms on the adsorption of Ni(II) by PHNA

adsorption for $\mathrm{Ni}(\mathrm{II})$ ions onto PHNA in the concentration range studied.

\section{Temkin isotherm model}

The Temkin (Kalavathy et al. 2010; Temkin and Pyzhev 1940) isotherm assumes that the fall in the heat of adsorption is linear rather than logarithmic, as implied in the Freundlich equation. The Temkin isotherm has generally been applied in the following form:
$q_{\mathrm{e}}=B \ln A+B \ln C_{\mathrm{e}}$

where

$B=\frac{R T}{b}$

A plot of $q_{\mathrm{e}}$ versus $\ln C_{\mathrm{e}}$ enables the determination of the isotherm constants $\mathrm{B}$ and $\mathrm{A}$ from the slope and the intercept, respectively (Fig. 5b). Constant $A$ is the equilibrium binding constant $(\mathrm{L} / \mathrm{mg})$ corresponding to the maximum binding energy, and constant $B$ is related to the heat of adsorption (Table 1).

\section{Dubinin-Radushkevich isotherm}

The D-R isotherm is an empirical model initially conceived for the adsorption of subcritical vapors onto micropore solids following a pore-filling mechanism (Dubinin and Radushkevich 1947). The D-R isotherm is more general than the Langmuir isotherm, because it does not assume a homogenous surface or constant sorption potential (Oguz 2005). In order to estimate the characteristic porosity of the adsorbent and the apparent energy of adsorption, the $\mathrm{Ni}(\mathrm{II})$ adsorption data were also fitted to the D-R isotherm in the following form (Jnr and Spiff 2005):

$q_{\mathrm{e}}=q_{\mathrm{m}} \exp \left(-K \varepsilon^{2}\right)$

Where $q_{\mathrm{e}}$ is the amount of $\mathrm{Ni}(\mathrm{II})$ ions adsorbed at equilibrium $(\mathrm{mg} / \mathrm{g}), K$ is a constant related to the mean-free energy of adsorption, and $q_{\mathrm{m}}$ is the maximum sorption capacity. The values of $q_{\mathrm{m}}$ and $\mathrm{K}$ were determined by plotting $\operatorname{lnq}_{\mathrm{e}}$ versus $\varepsilon^{2}$ (Fig. $5 \mathrm{c}$ ), and $\varepsilon$ is the Polanyi potential expressed as follows:

$\varepsilon=R T \ln \left(1+\frac{1}{C_{\mathrm{e}}}\right)$

Where $R$ is the gas constant $(\mathrm{kJ} / \mathrm{mol} . \mathrm{K})$ and $T$ is the temperature $(\mathrm{K})$. The values of sorption energy $E_{\mathrm{s}}(\mathrm{kJ} / \mathrm{mol})$ can be calculated from the Eq. (9):

$E_{\mathrm{s}}=\frac{1}{\sqrt{2 K}}$

The adsorption parameter, $\mathrm{K}$, was found to be $0.435 \mathrm{~kJ} /$ $\mathrm{mol}^{2}$ with high adsorption capacity, $q_{\mathrm{m}}=34.22 \mathrm{mg} / \mathrm{g}$. The mean sorption energy, $E_{\mathrm{s}}$, was $0.033 \mathrm{~kJ} / \mathrm{mol}$. The values of $E_{\mathrm{s}}$ between 1 and $8 \mathrm{~kJ} / \mathrm{mol}$ are typical of physisorption, whereas values in excess of this range indicate that ion- 
Table 3 Maximum monolayer adsorption capacities of various adsorbent

\begin{tabular}{|c|c|c|}
\hline Adsorbent & $\begin{array}{l}q_{\mathrm{m}}(\mathrm{mg} / \\
\mathrm{g})\end{array}$ & Reference \\
\hline Parthenium & 54.35 & Kadirvelu et al. (2002) \\
\hline Hevea brasiliensis & 17.21 & Kalavathy et al. (2010) \\
\hline Almond husk & 37.10 & Hasar (2003) \\
\hline Pomegranate peel & 52.20 & $\begin{array}{l}\text { Bhatnagara and Minochaa } \\
\text { (2010) }\end{array}$ \\
\hline Waste of tea factory & 18.40 & Malkoc and Nuhoglu (2005) \\
\hline Hazelnut shell & 10.10 & Demirbas, et al. (2002) \\
\hline Maize cob & 57.50 & Selvakumari et al. (2002) \\
\hline Litchi chinensis seeds & 66.62 & Flores-Garnica et al. (2013) \\
\hline Watermelon rind & 35.30 & $\begin{array}{l}\text { Lakshmipathy and Sarada } \\
\text { (2013) }\end{array}$ \\
\hline $\begin{array}{l}\text { Fungal biomass } \\
\text { isolated }\end{array}$ & 33.00 & Aytar et al. (2014) \\
\hline Peganum harmala- $\mathrm{L}$ & 68.02 & This study \\
\hline
\end{tabular}

exchange and chemisorption could be the dominant adsorption mechanisms. The D-R isotherm therefore related to the heterogeneity of energies of the adsorbent sites in PHNA which was consistent with electrostatic interactions between adsorbent sites and $\mathrm{Ni}(\mathrm{II})$ ions.

The sorption isotherm parameters are listed in Table 1. By comparing the squared correlation coefficients $\left(R^{2}\right)$ obtained from the four isotherm models, the Langmuir model gave the best correlation for the sorption process. The Langmuir model is in agreement with the experimental value, which suggests monolayer coverage of $\mathrm{Ni}(\mathrm{II})$ ions on the outer surface of the adsorbent. This means that the adsorption of ions takes place at specific homogeneous sites. The greatest equilibrium adsorption capacity obtained for $\mathrm{Ni}(\mathrm{II})$ is $68.02 \mathrm{mg} / \mathrm{g}$.

\section{Comparison of PHNA with other adsorbents}

The values of maximum monolayer adsorption capacities of PHNA adsorbent for the removal of $\mathrm{Ni}$ (II) ions have been compared with those of other adsorbents are shown in Table 3. The results in Table 3 indicate that PHNA has comparable adsorption capacities compared with other adsorbents.

\section{Kinetic studies}

There are essentially three stages in the adsorption process by porous adsorbents (Mckay 1984): (a) film resistance: Solute transfer from the bulk solution to the external surface of the sorbent through a liquid boundary layer; (b) intraparticle resistance: Solute transfer from the sorbent surface to the intra-particle active sites and (c) reaction resistance:
Interactions of the solute with the available sites on both the external and internal surfaces of the sorbent. One or more of the mentioned stages may control the rate at which the solute is adsorbed and the amount of solute that is adsorbed onto the sorbent. Several models can be used to express the mechanism of solute sorption onto a sorbent. In order to design a fast and effective model, investigations were made on adsorption rate. For the examination of the controlling mechanisms of the adsorption process, such as chemical reaction, diffusion control and mass transfer, several kinetics models are used to test the experimental data.

The conformity between the experimental data and the model predicted values was expressed by the correlation coefficients $\left(R^{2}\right)$. A relatively high $R^{2}$ value indicates that the model successfully describes the kinetics of the nitrobenzene adsorption (Wen et al. 2012).

The pseudo-first-order or Lagergren (1898) and pseudosecond-order or Ho and Mckay (1999) kinetic models were selected to test the adsorption dynamics in this study due to their good applicability in most cases in comparison with the first- and second-order models.

The pseudo-first-order kinetic model assumes that the rate of occupation of sorption sites is proportional to the number of unoccupied sites (Salam 2013).

The pseudo-first-order equation is generally represented as follows:

$\frac{\mathrm{d} q_{t}}{\mathrm{~d} t}=K_{1}\left(q_{\mathrm{e}}-q_{t}\right)$

After integration by applying conditions, $q_{t}=0$ at $t=0$ and $q_{t}=q_{t}$ at $t=t$, then Eq. (10) becomes:

$\log \left(q_{\mathrm{e}}-q_{t}\right)=\log q_{\mathrm{e}}-\frac{K_{1}}{2.303} t$

Data were applied to the pseudo-second- order kinetic rate equation which is expressed as follows:

$\frac{\mathrm{d} q_{t}}{\mathrm{~d} t}=K_{2}\left(q_{\mathrm{e}}-q_{t}\right)^{2}$

By applying the boundary conditions and integrating Eq. (12) gave:

$\frac{t}{q_{t}}=\frac{1}{K_{2} q_{\mathrm{e}}^{2}}+\frac{1}{q_{\mathrm{e}}} t$

where $q_{t}$ is the amount of $\mathrm{Ni}(\mathrm{II})(\mathrm{mg} / \mathrm{g})$ adsorbed at time $t$, $q_{\mathrm{e}}$ is the amount of $\mathrm{Ni}(\mathrm{II})(\mathrm{mg} / \mathrm{g})$ adsorbed at equilibrium, and $k_{1}\left(\mathrm{~min}^{-1}\right)$ and $k_{2}(\mathrm{mg} / \mathrm{g}$.min) are the rate constants of the first- and second-order kinetic equations of the adsorption.

The uptake of a sorbate onto the adsorbent is involves film diffusion, pore diffusion and intra-particlar diffusion (Nadeem et al. 2006). The intra-particlar diffusion and the pore diffusion are often rate limiting in a batch reactor (Goswami and Ghosh 2005). 

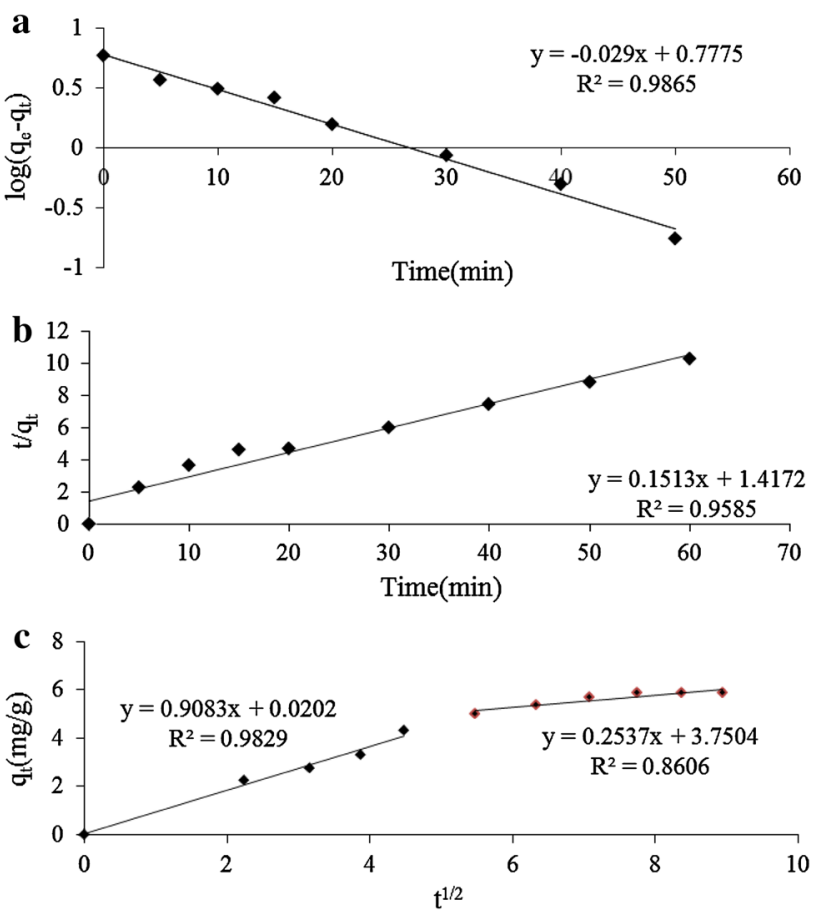

Fig. 6 a Pseudo-first-order kinetic, b pseudo-second-order kinetic and $\mathbf{c}$ intra-particular diffusion for adsorption of Ni(II) by PHNA

For porous adsorbents, the diffusion of the adsorbate molecules or ions into the pores is also to be taken into account to find a suitable kinetic model for the process (Ghasemi et al. 2013a, b). Intra-particular diffusion (Argun and Dursun 2008) is characterized by the relationship between specific sorption $\left(q_{t}\right)$ and the squared root of time $\left(t^{1 / 2}\right)$. This relation is shown as follows:

$q_{t}=k_{d} t^{1 / 2}+y$

Where $\mathrm{q}_{\mathrm{t}}$ is the amount of $\mathrm{Ni}(\mathrm{II})$ ions adsorbed at time $t(\mathrm{mg} / \mathrm{g}), k_{\mathrm{d}}$ is the initial rate of intra-particular diffusion $\left(\mathrm{mg} / \mathrm{g} \min ^{0.5}\right)$, and $\mathrm{y}$ is the intercept. Value of $y$ gives an idea about the thickness of the boundary layer as the larger the intercept the greater the boundary layer effect.

According to this model, the plot of uptake should be linear if intra-particular diffusion is involved in the adsorption process and if these lines pass through the origin then intra-particular diffusion is the rate-controlling step. When the plots do not pass through the origin, this is indicative of some degree of boundary layer control and shows that the intra-particular diffusion is not only the rate-limiting step, but also other kinetic models may control the rate of adsorption, all of which may be operating simultaneously (Mahmoodi et al. 2011). The parameters obtained from these models, pseudo-first-order (Fig. 6a), pseudo-second-order (Fig. 6b) and Intra-particular diffusion (Fig. 6c) plots for $\mathrm{Ni}(\mathrm{II})$ are compared in Table 4. It shows a good agreement between the calculated $q_{\mathrm{e}}$ and the experimental data. Thus,
Table 4 Kinetics constants for the adsorption of Ni(II) on PHNA

\begin{tabular}{lll}
\hline Absorbent & Peganum harmala-L & \\
\hline$q_{\text {eexp }}(\mathrm{mg} / \mathrm{g})$ & 5.86 & \\
Pseudo-first-order kinetics & $q_{\mathrm{e} \text { cal }}$ & 5.991 \\
& $K 1$ & 0.066 \\
& $R^{2}$ & 0.986 \\
Pseudo-second-order kinetics & $q_{\mathrm{e} \text { cal }}$ & 6.609 \\
& $K_{2}$ & 0.016 \\
& $R^{2}$ & 0.958 \\
Intra-particle mass transfer & $k_{\mathrm{d}, 1}$ & 0.983 \\
& $Y$ & 0.020 \\
& $R^{2}$ & 0.982 \\
& $k_{\mathrm{d}, 2}$ & 0.253 \\
& $Y$ & 3.750 \\
& $R^{2}$ & 0.860 \\
\hline
\end{tabular}

the results of experiments show that the pseudo-first-order model fits the experimental data quite well, as most of the $R^{2}$ values were greater than 0.98 . This indicates the applicability of the Lagergren kinetic model to describe the adsorption process of Ni(II) onto PHNA.

Figure $6 \mathrm{c}$ shows that the intra-particular adsorption plots are not linear over the whole time range and can be separated into two linear regions. No plots of intra-particle diffusion passed through the origin that indicates intraparticle diffusion was not only rate-controlling step although it was involved in the process. These plots represent the two different stages viz. external mass transfer followed by intra-particle diffusion signified that the ions were transported to the external surface of the PHNA particle through film diffusion (rate very fast step). After that, ions were entered into PHNA particles by intra-particle diffusion through pores (slowest one and rate-determining step). As shown in Fig. 6c, it could be inferred that external surface adsorption (stage 1) was completed before $20 \mathrm{~min}$ after which the stage of intra-particle diffusion (stage 2) commenced and continued from 20 to $60 \mathrm{~min}$. Final equilibrium adsorption (stage 3) started after $60 \mathrm{~min}$, the $\mathrm{Ni}$ (II) ions were slowly transported into the particles via intraparticle or pore diffusion and finally retained in the micropores of the PHNA. Generally, when adsorption steps are not dependent of one another, the plot of $q_{\mathrm{t}}$ against $t^{1 / 2}$ should give two or more intercepting lines depending on the actual mechanism (Dawood and Sen 2012).

\section{Conclusion}

Natural adsorbent was prepared by pretreatment of $P$. harmala-L. Its adsorption performance was evaluated using $\mathrm{Ni}(\mathrm{II})$ in an aqueous solution. The results showed that 
the adsorption is a rather fast process. The adsorption process could be represented by a pseudo-first-order rate model for metal ion. The rate constant $\left(K_{1}\right)$ was $0.066 \mathrm{~min}^{-1}$ for $50 \mathrm{mg} / \mathrm{L}$. In terms of removal percentage, for $\mathrm{Ni}(\mathrm{II})$, the removal percentage remains approximately $58.622 \%$. Langmuir adsorption isotherm model describes adsorption behavior. The maximum adsorption capacity of the PHNA adsorbent for $\mathrm{Ni}(\mathrm{II})$ was equal to $68.02 \mathrm{mg} / \mathrm{g}$.

Acknowledgments The authors thank from Dr Amir Rahimi and maryam montazerghaem (University of Esfahan) and factually of science, Islamic Azad University, Department of Chemistry.

\section{References}

ALzaydien AS (2009) Adsorption of methylene blue from aqueous solution onto a low-cost natural Jordanian Tripoli. Am J Environ Sci 5:197-208

Argun ME, Dursun S (2008) A new approach to modification of natural adsorbent for heavy metal adsorption. Bioresour Technol 99:2516-2527

Aytar P, Gedikli S, Buruk Y, Burnak N, Cabuk A (2014) Lead and nickel biosorption with a fungal biomass isolated from metal mine drainage: Box-Behnken experimental design. Int J Environ Sci Technol. doi:10.1007/s13762-013-0354-5

Bhatnagara A, Minochaa AK (2010) Biosorption optimization of nickel removal from water using Punica granatum peel waste. Colloids Surf B Biointerfaces 76:544-548

Carvalho WA, Vignado C, Fontana J (2008) Ni(II) removal from aqueous solution effluents by silylated clays. J Hazard Mater 153:1240-1247

Chen H, Zhao J, Dai G, Wu J, Yan H (2010) Adsorption characteristics of $\mathrm{Pb}$ (II) from aqueous solution onto a natural biosorbent fallen Cinnamomum camphora leaves. Desalination 262(1-3):174-182

Colak F, Olgun A, Atar N, Yazıcıglu D (2013) Heavy metal resistances and biosorptive behaviors of Paenibacillus polymyxa: batch and column studies. J Ind Eng Chem 19:863-869

Dai X, Breuer PL, Jeffrey MI (2010) Comparison of activated carbon and ion-exchange resins in recovering copper from cyanide leach solutions. Hydrometallurgy 101:48-57

Darabpour E, Poshtkouhian Bavi A, Motamedi H, Seyyed Nejad SM (2011) Antibacterial activity of different parts of Peganum harmala L. growing in Iran against multi-drug resistant bacteria. EXCLI J 10:252-263

Dawood S, Sen TK (2012) Removal of anionic dye Congo red from aqueous solution by raw pine and acid-treated pine cone powder as adsorbent: equilibrium, thermodynamic, kinetics, mechanism and process design. Water Res 46:1933-1946

Demirbas E, Kobya M, Oncel S, Sencan S (2002) Removal of Ni(II) from aqueous solution by adsorption onto hazelnut shell activated carbon: equilibrium studies. Bioresour Technol 84:291-293

Dubinin MM, Radushkevich LV (1947) The equation of the characteristic curve of the activated charcoal. Proc Acad Sci USSR Phys Chem Sect 55:331-337

El Gendy MAM, El-Kadi AOS (2009) Peganum harmala L. differentially modulates cytochrome $\mathrm{P} 450$ gene expression in human hepatoma HepG2 cells. Drug Metab Lett 3:212-216

Esmaili-Sari A, Zolfaghari G, Younesi H, Anbia M, Ghasemian MB (2013) A zinc oxide-coated nanoporous carbon adsorbent for lead removal from water: optimization, equilibrium modeling, and kinetics studies. Int J Environ Sci Technol 10(2):325-340

Flores-Garnica JG, Morales-Barrera L, Pineda-Camacho G, CristianiUrbina E (2013) Biosorption of Ni (II) from aqueous solutions by Litchi chinensis seeds. Bioresour Technol 136:635-643

Fu F, Wang Q (2011) Removal of heavy metal ions from wastewaters: a review. J Environ Manag 92:407-418

Ghasemi N, Ghasemi M, Khosravi-Fard Y (2013) The Sorption of $\mathrm{Ni}(\mathrm{II})$ by grape shell ash from aqueous solution: kinetic and thermodynamic studies. Indian J Mater Sci, Article ID 248138, 6

Ghasemi M, Naushad M, Ghasemi N, Khosravi-fard Y (2013) Adsorption of $\mathrm{Pb}$ (II) from aqueous solution using new adsorbents prepared from agricultural waste: adsorption isotherm and kinetic studies. J Ind Eng Chem. http://dx.doi.org/10.1016/j.jiec. 2013.09.050

Ghasemi M, Naushad M, Ghasemi N, Khosravi-fard Y (2014) A novel agricultural waste based adsorbent for the removal of $\mathrm{Pb}$ (II) from aqueous solution: kinetics, equilibrium and thermodynamic studies. J Ind Eng Chem 20:454-461

Goel N, Singh N, Saini R (2009) Efficient in vitro multiplication of Syrian Rue (Peganum harmala L.) using 6-benzylaminopurine pre conditioned seedling explants. Nat Sci 7(7):129-134

Goswami S, Ghosh US (2005) Studies on adsorption behaviour of $\mathrm{Cr}(\mathrm{VI})$ onto synthetic hydrous stannic oxide. Water SA 31(4):597-602

Gupta N, Balomajumder Ch, Agarwal VK (2012) Adsorption of cyanide ion on pressmud surface: a modeling approach. Chem Eng J 191:548-556

Hasar H (2003) Adsorption of nickel (II) from aqueous solution onto activated carbon prepared from almond husk. J Hazard Mater 97:49-57

Ho YS, McKay G (1999) Pseudo-second order model for sorption processes. Process Biochem 34:451-465

Ho YSh, Ofomaja AE (2006) Biosorption thermodynamics of cadmium on coconut copra meal as biosorbent. Biochem Eng J 30:117-123

Jnr HM, Spiff AI (2005) Equilibrium sorption study of $\mathrm{Al}^{3+}, \mathrm{Co}^{2+}$ and $\mathrm{Ag}^{+}$in aqueous solutions by fluted pumpkin (Telfairia Occidentalis HOOK f) waste biomass. Acta Chim Slov 52:174-181

Huang L, Sun Y, Yang T, Li L (2011) Adsorption behavior of Ni (II) on lotus stalks derived active carbon by phosphoric acid activation. Desalination 268:12-19

Hui KS, Chao CYH, Kot SC (2005) Removal of mixed heavy metal ions in wastewater by zeolite 4A and residual products from recycled coal fly ash. J Hazard Mater 127:89-101

Jamali AH, Mahvi AH, Nazmara S (2009) Removal of cadmium from aqueous solution by hazelnut shell. World Appl Sci J 5:16-20

Kadirvelu K, Senthilkumar P, Thamaraiselvi K, Subburam V (2002) Activated carbon prepared from biomass as adsorbent: elimination of Ni (II) from aqueous solution. Bioresour Tech 81:87-90

Kalavathy H, Karthik B, Miranda LR (2010) Removal and recovery of $\mathrm{Ni}$ and $\mathrm{Zn}$ from aqueous solution using activated carbon from Hevea brasiliensis: batch and column studies. Colloids Surfaces B 78:291-302

Lagergren S (1898) About the theory of so-called adsorption of soluble substances. Kung. Sven Vetensk Handl 24:1-39

Lakshmipathy R, Sarada NC (2013) Application of watermelon rind as sorbent for removal of nickel and cobalt from aqueous solution. Int J Mineral Process 122:63-65

Lalhruaitluanga H, Prasad MNV, Radha K (2011) Potential of chemically activated and raw charcoals of Melocanna baccifera for removal of $\mathrm{Ni}(\mathrm{II})$ and $\mathrm{Zn}$ (II) from aqueous solutions. Desalination 271:301-308

Langmuir I (1918) Adsorption of gases on plain surface of glass mica platinum. J Am Chem Soc 40:1361-1403 
Mahmoodi NM, Salehi R, Arami M (2011) Binary system dye removal from colored textile wastewater using activated carbon: kinetic and isotherm studies. Desalination 272:187-195

Malkoc E, Nuhoglu Y (2005) Investigations of nickel(II) removal from aqueous solutions using tea factory waste. J Hazard Mater 127:120-128

McKay G (1984) The adsorption of basic dye onto silica from aqueous-solution solid diffusion-model. Chem Eng Sci 39:129-138

Nadeem M, Mahmood A, Shahid SA, Khalid AM, Mckay G (2006) Sorption of lead from aqueous solution by chemically modified carbon adsorbent. J Hazard Mater 138(3):604-613

Namasivayam C, Yamuna RT, Jayanthi J (2003) Removal of methylene blue from wastewater by adsorption on cellulosic waste, orange peel. Cell Chem Technol 37:333-339

Oguz E (2005) Thermodynamic and kinetic investigations of $\mathrm{PO}_{4}{ }^{3-}$ adsorption on blast furnace slag. $\mathrm{J}$ Colloid Interface Sci 281:62-67

Salam MA (2013) Removal of heavy metal ions from aqueous solutions with multi-walled carbon nanotubes: kinetic and thermodynamic studies. Int J Environ Sci Technol 10(4):677-688

Selvakumari G, Murugesan M, Pattabi S, Sathishkumar M (2002) Treatment of electroplating industry effluent by maize cob carbon. Bull Environ Contam Toxicol 69:195-202
SenthilKumar P, Ramalingam S, Sathyaselvabala V, Kirupha DS, Sivanesan S (2011) Removal of copper (II) ions from aqueous solution by adsorption using cashew nut shell. Desalination 266(1-3):63-71

Temkin MJ, Pyzhev V (1940) Kinetics of ammonia synthesis on promoted iron catalysis. Acta Physiochim URSS 12:327-356

Wahi R, Kanakaraju D, Yusuf NA (2010) Preliminary study on zinc removal from aqueous solution by sago wastes. Glob J Environ Res 4:127-134

Wen Q, Chen ZH, Lian J, Feng Y, Ren N (2012) Removal of nitrobenzene from aqueous solution by a novel lipoid adsorption material (LAM). J Hazard Mater 209-210:226-232

Zhang T, Ding L, Ren H, Xiong X (2009) Ammonium nitrogen removal from coking wastewater by chemical precipitation recycle technology. Water Res 43:5209-5215

Zhu K, Fu H, Zhang J, Lv X, Tang J, Xu X (2012) Studies on removal of $\mathrm{NH}_{4}{ }^{+}-\mathrm{N}$ from aqueous solution by using the activated carbons derived from rice husk. Biomass Bioenergy 43:18-25

Zou H, Jin Y, Yang J, Dai H, Yu X, Xu J (2010) Synthesis and characterization of thin film composite reverse osmosis membranes via novel interfacial polymerization approach. Sep Purif Technol 72:256-262 